DRUŠ. ISTRAŽ. ZAGREB

GOD. 20 (2011)

STR. 899-911

Završna cjelina knjige $S$ onu stranu monokulture posvećena je naracijama iz Kutereva. Kao što je već spomenuto, na temelju istraživanja, konkretnije (terenskog) kvalitativnog istraživanja, ili bolje rečeno, pomoću "metodologije kao bricolagea", autorica je došla do empirijskih podataka važnih za svoj rad. Marija Geiger boravila je u ličkom selu Kuterevu, upoznavala lokalnu kulturu, stanovništvo, njihov mentalitet, tradiciju, običaje. Ono što je važno, upoznala je njihov odnos prema okolišu - lokalnu ekologiju, okolišne prakse i sisteme upravljanja lokalnim resursima, lokalni $e$ thos, okolišne aspekte kuterevske duhovnosti i njihove svjetonazorske tendencije. Autorica, naravno, nije zaboravila ni rodnu dimenziju cijele ove priče, pa donosi i posebno poglavlje o rodnoj podjeli tradicijskih znanja i vještina. Čvrstu teorijsku podlogu, koju je postavila u prva dva dijela knjige, Marija Geiger uspjela je potkrijepiti i odgovarajućim kvalitativnim istraživanjem, koje bi trebalo poslužiti kao primjer predana i kvalitetna rada svakom (mladom) znanstveniku (s područja društvenih i humanističkih znanosti) u Hrvatskoj.

Kao što je, recenzirajući ovaj rad, napomenuo prof. dr. sc. Rade Kalanj, ova je knjiga poučna i zanimljiva ne samo znanstvenicima društvenih i humanističkih znanosti nego i svima onima koji nastoje na očuvanju prirode i održivu odnosu prema okolišu, kako bismo bolje živjeli mi sami, naši suvremenici i generacije koje dolaze.

Konačno, najprikladnije je završiti riječima same autorice, koja naglašava važnost malih, lokalnih priča, upravo zbog toga što prošlost mjesta kao što je Kuterevo može savjetovati sadašnjost kako da osigura lokalnu održivu budućnost.

Anita Bušljeta

\section{doi:10.5559/di.20.3.17 \\ Damir Demonja, Pavl• Ružić \\ RURALNI TURIZAM \\ U HRVATSKOJ S HRVATSKIM PRIMJERIMA DOBRE PRAKSE I EUROPSKIM ISKUSTVIMA}

Meridijani, Zagreb, 2010., 316 str.

"Ruralni turizam skupni je naziv za različite aktivnosti i oblike turizma koji se razvijaju na ruralnom prostoru. On se ostvaruje unutar prirodnih i kulturnih resursa na ruralnim područjima, koji omogućavaju brojne turističke aktivnosti i oblikuju veliki broj različitih oblika turizma. Ruralni prostor $\mathrm{u}$ Hrvatskoj zauzima 91,6\% njezine površine i obilježava ga velika bio i društvena raznolikost, što predstavlja ogromni potencijal za razvoj ruralnog turizma". Tim riječima autori knjige Ruralni turizam $u \mathrm{Hr}$ vatskoj s hrvatskim primjerima dobre prakse $i$ europskim iskustvima, Damir Demonja i Pavlo Ružić, započinju predgovor i uvode čitatelje u temu ruralnoga turizma, čime nagovještavaju kako tekst problematizira definiranje samoga pojma ruralnoga turizma, a onda i mogućnosti koje njegov razvoj može donijeti Hrvatskoj.

U zadnje se vrijeme mnogo govori o mogućnostima razvoja ruralnoga turizma u Hrvatskoj, na tu je temu održano nekoliko javnih skupova, konferencija, ljetnih škola, a referentne institucije, odnosno javna tijela, uveli su niz poticajnih mjera za njegov razvoj. Osim toga, opaža se i niz privatnih inicijativa pojedinaca koji su se odlučili na takvu vrstu poslovanja.

Sama činjenica da je Hrvatska turistička zemlja možda i ne ide u prilog popularnosti ruralnoga turizma, jer se turizam $\mathrm{u}$ nas usredotočuje $\mathrm{u}$ prvom redu na masovni obalni turizam, dok su ostali, selek- 
DRUŠ. ISTRAŽ. ZAGREB

GOD. 20 (2011),

BR. 3 (113)

STR. 899-911 I PRIKAZ | tivni oblici turizma, razvijeni u osjetno manjem opsegu. Ipak, sve manja javna nacionalna sredstva, gospodarska kriza, mogućnosti koje se pružaju iz EU fondova, velik dio ruralnoga prostora u Hrvatskoj kao i činjenica da još uvijek, u usporedbi s ostalim zapadnoeuropskim zemljama, imamo relativno zdravu i ekološku poljoprivrednu proizvodnju koja ima mogućnosti plasmana u turizmu utjecali su na potrebu promišljanja o drugačijim oblicima poslovanja. Kako se turizam (iako ponekad pogrešno) već dugo pokazuje kao relativno brz i lak način zarade, nije neobično što baš u ovom trenutku na tržište izlazi knjiga ovakve tematike.

Ukupno ima osam poglavlja, uz iscrpno poglavlje s izvorima literature, koja na logičan način zaokružuju temu ruralnoga turizma, počevši od njegova definiranja, preko stanja ruralnoga turizma $\mathrm{u} \mathrm{Hr}$ vatskoj, do onoga u Europi. Krug se završava zaključcima i preporukama za održiv razvoj ruralnoga turizma u Hrvatskoj.

Prvo poglavlje, Osnove ruralnog turizma, najprije obrađuje terminologiju ruralnoga turizma, za koji se rabe razne istoznačnice, ali i termini koji se razlikuju i u semantičkom smislu i u opsegu i razumijevanju ruralnoga prostora. Budući da množina definicija izaziva priličnu zbrku u razumijevanju te vrste turizma, prikazani su kriteriji Europske federacije ruralnoga turizma "Eurogites" (koji vrijede za Europu), po kojima se definira okvir ruralnoga turizma. Pomoć u definiranju ruralnoga turizma traži se i u njegovim oblicima, koji su detaljno obrađeni u ovom poglavlju.

Hrvatski ruralni turizam u knjizi se objašnjava u iduća četiri poglavlja. Uvodno poglavlje u ovu temu, naslovljeno $A k$ tualno stanje ruralnog turizma u Hrvatskoj, donosi brojčane podatke o ruralnim pod- ručjima u Hrvatskoj, a naslanja se i na Strategiju razvoja hrvatskog turizma do 2010., prema kojoj u ruralnim cjelinama postoje uvjeti za razvoj devetnaest oblika turizama. U ovom poglavlju iznose se podaci o stanju agroturizma u Hrvatskoj, a posebno o stanju svih ostalih oblika ruralnoga turizma, kao što su rezidencijalni, zavičajni (ili nostalgični), sportsko-rekreacijski, avanturistički, kulturni, vjerski, lovni, ribolovni, gastronomski, vinski, edukacijski, kamping, nautički i ekoturizam. Osim toga, poglavlje donosi informacije i o objektima, odnosno kapacitetima, ruralnoga turizma u $\mathrm{Hr}$ vatskoj, turističkom prometu i tržištu ruralnoga turizma te završava zaključcima dvaju kongresa o ruralnom turizmu, koji su održani u razmaku od 3 godine.

Razvoj ruralnog turizma u Hrvatskoj naslov je trećega poglavlja, koje nas uvodno informira o brojnim pretpostavkama za razvoj ruralnoga turizma u Hrvatskoj. One su normativnoga, organizacijskoga, edukacijskoga, razvojnoga, financijskoga i promidžbenoga karaktera. Potpoglavlje koje se usredotočuje na generički nazvane "ostale" pretpostavke dodatno navodi i uređenost seljačkoga turističkog gospodarstva, kao i atraktivnost ponude seljačkoga turizma. Činitelji razvoja ruralnoga turizma podijeljeni su na činitelje potražnje, koji mogu biti objektivni i subjektivni, te činitelje ponude. Potonje čine prirodne i socijalne atrakcije, prometna povezanost, ponuda te turističko posredovanje u ruralnom turizmu.

Četvrto poglavlje obrađuje Marketing u ruralnom turizmu te objašnjava istraživanje tržišta u ruralnom turizmu, promidžbu i prodaju.

Poglavlje Učinci ruralnog turizma $u$ Hrvatskoj na prilično opsežan način predstavlja utjecaj ruralnoga turizma na razne sektore, kao što su poljoprivreda, prostorno uređenje, zaštita okoliša, proizvodnja hrane, kultura, graditeljstvo, poduzetništvo itd. Autori su učinke ruralnoga turizma u Hrvatskoj podijelili na ekonomske i neekonomske, a predstavljen je i niz primjera dobre prakse poduzetničkih projekata, i to u sljedećim tržišnim segmentima: 
DRUŠ. ISTRAŽ. ZAGREB

GOD. 20 (2011)

BR. 3 (113),

STR. 899-911

turistička seljačka obiteljska gospodarstva, vinotočja, kušaonice, izletišta, smještaj na ruralnom prostoru, stara sela, ekogospodarstva, male etnografske zbirke, tematske ceste i putovi.

Europski trendovi u ruralnom turizmu te ključne međunarodne organizacije ruralnoga turizma tema su šestoga poglavlja naslovljenog Ruralni turizam u Europi danas. Poglavlje donosi i primjere financiranja iz fondova Europske unije, što može biti koristan početni vodič onima koji se žele baviti ruralnim turizmom.

Zaključci i preporuke za održivi razvoj ruralnog turizma u Hrvatskoj kao završno poglavlje oslanjaju se na europske preporuke za održivi razvoj te vrste turizma, a sežu od stvaranja zakonskih temelja i poreznih propisa, preko isticanja regionalnih posebnosti, primjene novih tehnologija $u$ premošćivanju izoliranosti seoskih zajednica, vrednovanja ljudskih resursa kao temelja za uspjeh u turizmu do očuvanja same životne sredine koja je osnovni resurs u ovoj vrsti turizma. Održivi razvoj ruralnoga turizma u Hrvatskoj, smatraju autori, trebao bi odgovoriti na sljedeća pitanja: kako zaštititi dosad čuvani prostor, koje su prednosti, a koja ograničenja razvoja određene regije, koju ulogu u razvoju imaju vlada i lokalna uprava, treba li razvoj graditi na kulturnoj, povijesnoj i gospodarskoj prepoznatljivosti ili je potrebno stvoriti neke druge pretpostavke te kako kreirati razvoj koji sam sebe neće dovesti do kolapsa.

Prema ocjeni recenzenata, "knjiga predstavlja vrlo iscrpan (...) izvor informacija i znanja o postojećem stanju ruralnog turizma, kao i snažan doprinos definiranju terminologije koja se koristi $u$ znanstvenim i stručnim krugovima". Iscrpan je izvor sekundarnih podataka iz pro- učavanoga područja, što dokazuje i opsežno poglavlje s literaturom. Osim za buduća znanstvena istraživanja, knjiga će biti korisna i primjenjiva i u stručnom smislu svima onima koji se bave ruralnim turizmom. Na taj je način dobrodošla dopuna uglavnom nedostatnoj literaturi o ovom području u Hrvatskoj.

Daniela Angelina Jelinčić

\section{doi:10.5559/di.20.3.18 \\ Marino Manin ISTRA NA RASKRIŽJU: - poviJesti migraciJa PUČANSTVA ISTRE}

Profil Multimedija i Institut za migracije i narodnosti, Zagreb, 2010., 171 str.

Monografija Marina Manina "Istra na raskrižju: O povijesti migracija pučanstva Istre", objavljena uz sunakladništvo Profil Multimedije i Instituta za migracije i narodnosti u jesen 2010., sastavljena je od šest znanstvenih radova, objavljenih u zadnjem desetljeću. Knjigu su recenzirali Ivan Čizmić i Darko Vitek.

Studije objedinjene u ovom izdanju, dosad raštrkane po časopisima i zbornicima, nastajale su u raznim prigodama, a premda obuhvaćaju širok vremenski raspon od ranoga novovjekovlja do druge polovice 20. stoljeća, povezuje ih očit autorov istraživački interes za prijelomne trenutke istarske povijesti, redovito popraćene migracijama stanovništva. Traumatična iskustva čitavih generacija istarskih stanovnika ostavljala su snažan pečat u kolektivnoj memoriji, zbog čega ni historiografija nije uvijek bila pošteđena paušalnih ocjena i pretjerivanja. Maninove su studije utemeljene na arhivskim i historiografskim istraživanjima, a relevantna literatura poslužila je u prvom redu kao oslonac vlastitim uvidima i zaključcima, što svaki od članaka čini doprinosom poznavanju istarske prošlosti. 